\title{
Probiotic feed additives - effectiveness and expected modes of action
}

\author{
O. Simon, A. Jadamus and W. Vahjen \\ Institute for Animal Nutrition. Faculty of Veterinary Medicine, \\ Free University of Berlin \\ Brümmerstr. 34, 14195 Berlin, Germany
}

\begin{abstract}
In animal nutrition, probiotics are viable microorganisms used as a feed supplement, which lead to beneficial effects for the host animal. For most species a trend towards improved performance has been reported due to the use of probiotics, but statistically significant improvements of weight gain and of feed conversion are rare, mainly because of variations in the individual reactions of the animals. However, reductions of the incidence of diarrhoea were significant in most studies with piglets and calves. In contrast to human nutrition, where Lactobacillus species are common probiotic products, in animal nutrition Enterococcus spp., Saccharomyces yeast, and spore-forming Bacillus spp. are most frequently used as probiotic microorganisms. Furhermore, in human nutrition long-term effects for lasting health promotion and longevity are sought, but the aims of probiotic supplementation in modern animal production are fast effects such as improvement of weight gain and feed conversion. Thus, results from probiotic rescarch in the ficld of human nutrition are not completely valid for animal nutrition.

Although 19 probiotic preparations have received temporary approval in the European Union, their modes of action, which lead to beneficial effects, are only partly known. It is very probable that the impact of probiotics on pathogenic and nonpathogenic intestinal bacteria is of prime importance. However, modifications of microstructures and barrier functions of intestinal tissues as well as reactions of the immune system seem to be involved in the overall effect, directly or as a consequence of modified bacterial populations. In order to specifically improve probiotics and their application in defined indications, more research is needed to determine their underlying mechanisms.
\end{abstract}

KEY WORDS: probiotic, bacteria, yeast, fungi, pig, poultry, cattle

\section{INTRODUCTION}

The concept of probiotics was first developed by Elie Metschnikoff, who tried to explain the exceptionally high life expectancy of rural inhabitants in parts of Bulgaria. Metschnikoff noted that these people consumed large amounts of fer- 
mented milk products (kefir) and in 1907 he proposed the hypothesis that bacteria in this special type of yogurt may be capable of controlling bacterial fermentation processes in the intestine and to prevent arteriosclerosis (Metschnikoff, 1907). Metschnikoff found high numbers of the bacterium Bacillus bulgaricus in kefir and proposed them as the responsible agent for the observed beneficial effects. Today we know that Bacillus bulgaricus actually was Lactobacillus acidophilus. This bacterium and other species of the Lactobacillus genus are considered to be probiotic bacteria with a health- promoting effect for humans (DiRienzo, 2000; Sanders, 2000).

In the last two decades the probiotic concept has also been applied to animal nutrition. In the nutrition of farm animals the probiotic definition by Fuller (1998) is generally accepted. He stated that probiotics are microorganisms, which are used as a feed additive and lead to beneficial effects for the host animal because of an "improvement of the intestinal microbial balance". This description on the mode of action of probiotics shows that there is still no hard data to precisely explain the observed positive results. Furthermore, research on probiotics mainly concentrates on the Lactobacillus genus, which plays an important role in human nutrition, but except for a few products, is not used as a feed additive for farm animals. There are even more differences between human and animal nutrition. Human probiotic foods such as yogurt are not consumed on a regular basis and mostly in relatively low amounts, while respective animal feedstuffs are always supplemented with a probiotic product. Thus, animals consume the probiotic additive in each meal in the same concentration $\left(10^{9}\right.$ viable bacteria $/ \mathrm{kg}$ feed), which leads to a constant supply of a probiotic strain to the animal.

The desired goals of probiotic action are also different. In human nutrition longterm effects for lasting health promotion and longevity are sought. This stands in strong contrast to the aim of probiotic supplementation in modern animal production, where fast effects such as improvement of weight gain and feed conversion prevail. For these reasons, results from probiotic research in the field of human nutrition are not completely valid for animal nutrition and thus there is a strong need for research on probiotics in this field.

\section{APPROVAL OF MICROORGANISMS AS FEED ADDITIVES}

The approval of probiotic microorganisms in the European Union is controlled by the European Commission. Before a product is approved as a feed additive in the EU, its effectiveness (zootechnical parameters, prevention of diarrhoea) has to be proven. Furthermore, its safety must be demonstrated. Probiotics may not endanger the health of the host or the working personal; they must be nonpathogenic and must not produce toxins. They must be non-invasive to the host tissue and may 
not contaminate animal products. Possible genetic transfer of antibiotic resistance must also be ruled out. For technical reasons the viability of the probiotic during feed production (temperature, pressure), stability against other feed components and during storage is also of importance.

Today (March 2001) 19 probiotic preparations have EU-approval as feed additives (Table 1). With one exception, all of the preparations have only temporary approvals. Thus, most probiotic preparations still have to provide further experimental data on their efficiency and lack of objections before indefinite approval will be given.

EFFICIENCY OF MICROORGANISMS AS FEED ADDITIVES FOR PIGS, POULTRY AND CALVES

Pigs

Verification of efficiency has been carried out mainly on suckling and weaning piglets. Weight gain, feed conversion and incidence of diarrhoea have been used as efficiency criteria. There are far fewer studies on efficiency with fattening pigs and sows.

According to a literature review in 1986 (Tuschy), no positive effects could be found from results with piglets and fattening pigs. Later, the evaluation of studies conducted with weaning piglets drew a different picture (Freitag et al., 1998; Figure 1).

This change in evaluation may be connected with the increasing number of tested microorganisms. The first studies were mainly carried out with bacteria of the genus Lactobacillus, but later studies included preparations consisting of $\mathrm{Ba}$ cillus spp. (preparations in spore form), Enterococcus faecium and Saccharomyces cerevisiae. In addition, the approach to probiotic evaluation has changed. Tuschy (1986) used the strict criteria of biostatistics and only significant effects were documented. Today, trends without statistical significance are also considered as positive effects. This may not be correct from the scientific point of view, but should not be rejected as will be explained below. As can be seen from Figure 1, most studies with weaning piglets show positive effects of probiotics on weight gain and feed conversion, some studies show no or adverse effects. Furthermore, even feeding trials with positive effects in the range of $5 \%$ or more were rarely statistically significant. This indicates strong differences in the individual reactions of the animals toward the probiotic and leads to the general conclusion that the probiotic effect is not as consistent as other feed additives such as antibiotics. The evaluation of probiotics in this regard is especially important because of the expected general ban of antibiotics as feed additives in the EU. 
TABLE 1

Probiotic preparations with temporary approval as feed additive (European Commission on Health and Consumer Protection, March, 2001)

\begin{tabular}{|c|c|c|}
\hline Mikroorganism & Registration number & Animal species \\
\hline Bacillus cereus var, toyoi & $\begin{array}{l}\text { NCCIB 40112/ } \\
\text { CNCM } 11012 i\end{array}$ & $\begin{array}{l}\text { Piglet, pigs, sows } \\
\text { Calves, cattle } \\
\text { Broiler, layer hens } \\
\text { Rabbits }\end{array}$ \\
\hline Bacillus cereus & ATCC 14893 & $\begin{array}{l}\text { Piglet, fattening pigs, sows } \\
\text { Calves } \\
\text { Broiler, turkeys } \\
\text { Rabbits }\end{array}$ \\
\hline $\begin{array}{l}\text { Bacillus licheniformis } \\
\text { Bacillus subtilis' }\end{array}$ & $\begin{array}{l}\text { DSM } 5749 \\
\text { DSM } 5750\end{array}$ & $\begin{array}{l}\text { Piglet, fattening pigs, sows } \\
\text { Calves } \\
\text { Broiler, turkeys }\end{array}$ \\
\hline $\begin{array}{l}\text { Enterococcus faecium } \\
\text { Lactobacillus rhamnosus } \\
\text { Enterococcus faecium }\end{array}$ & $\begin{array}{l}\text { DSM } 7134 \\
\text { DSM } 7133 \\
\text { NCIMB } 10415\end{array}$ & $\begin{array}{l}\text { Piglet } \\
\text { Calves } \\
\text { Piglet, fattening pigs, sows } \\
\text { Calves, cattle } \\
\text { Broiler }\end{array}$ \\
\hline Enterococcus faecium & NC1MB 11181 & $\begin{array}{l}\text { Piglet } \\
\text { Calves }\end{array}$ \\
\hline Enterococcus faecium & DSM 5464 & $\begin{array}{l}\text { Piglet } \\
\text { Calves } \\
\text { Broiler }\end{array}$ \\
\hline Enterococcus foecium & $\begin{array}{l}\text { DSM 10663/ } \\
\text { NCIMB } 10415\end{array}$ & $\begin{array}{l}\text { Piglet } \\
\text { Calves } \\
\text { Broiler }\end{array}$ \\
\hline $\begin{array}{l}\text { Enterococcus faecium } \\
\text { Enterococcus faecium }\end{array}$ & $\begin{array}{l}\text { ATCC } 53519 \\
\text { ATCC } 55593\end{array}$ & Broiler \\
\hline Enterococcus faecium & CECT 4515 & $\begin{array}{l}\text { Piglet } \\
\text { Calves }\end{array}$ \\
\hline $\begin{array}{l}\text { Lactobacillus casei } \\
\text { Enterococcus faecium }\end{array}$ & $\begin{array}{l}\text { NCIMB } 30096 \\
\text { NCIMB } 30098\end{array}$ & Calves \\
\hline Lactobacillus farciminis & CNCM MA $67 / 4 \mathrm{R}$ & Piglet \\
\hline Pediococcus acidilactici & CNCM MA $18 / 5 \mathrm{M}$ & $\begin{array}{l}\text { Piglet, fattening pigs } \\
\text { Broiler }\end{array}$ \\
\hline Saccharomyces cerevisiae & NCYC Sc 47 & $\begin{array}{l}\text { Piglet, sows } \\
\text { Cattle } \\
\text { Rabbits }\end{array}$ \\
\hline Saccharomyces cerevisiae & MUCL 39885 & $\begin{array}{l}\text { Piglet } \\
\text { Cattle }\end{array}$ \\
\hline Saccharomyces cerevisiae & CNCM I- 1079 & Piglet, sows \\
\hline $\begin{array}{l}\text { Saccharomyces cerevisiae } \\
\text { Saccharomyces cerevisiae } \\
\text { Streptococcus infantarius } \\
\text { Lactobacillus plantarum }\end{array}$ & $\begin{array}{l}\text { CNCM I- } 1077 \\
\text { CBS } 49394 \\
\text { CNCM I-841 } \\
\text { CNCM I-840 }\end{array}$ & $\begin{array}{l}\text { Dairy cows, cattle } \\
\text { Calves, cattle } \\
\text { Calves }\end{array}$ \\
\hline
\end{tabular}

1 indefinite approval for piglets 

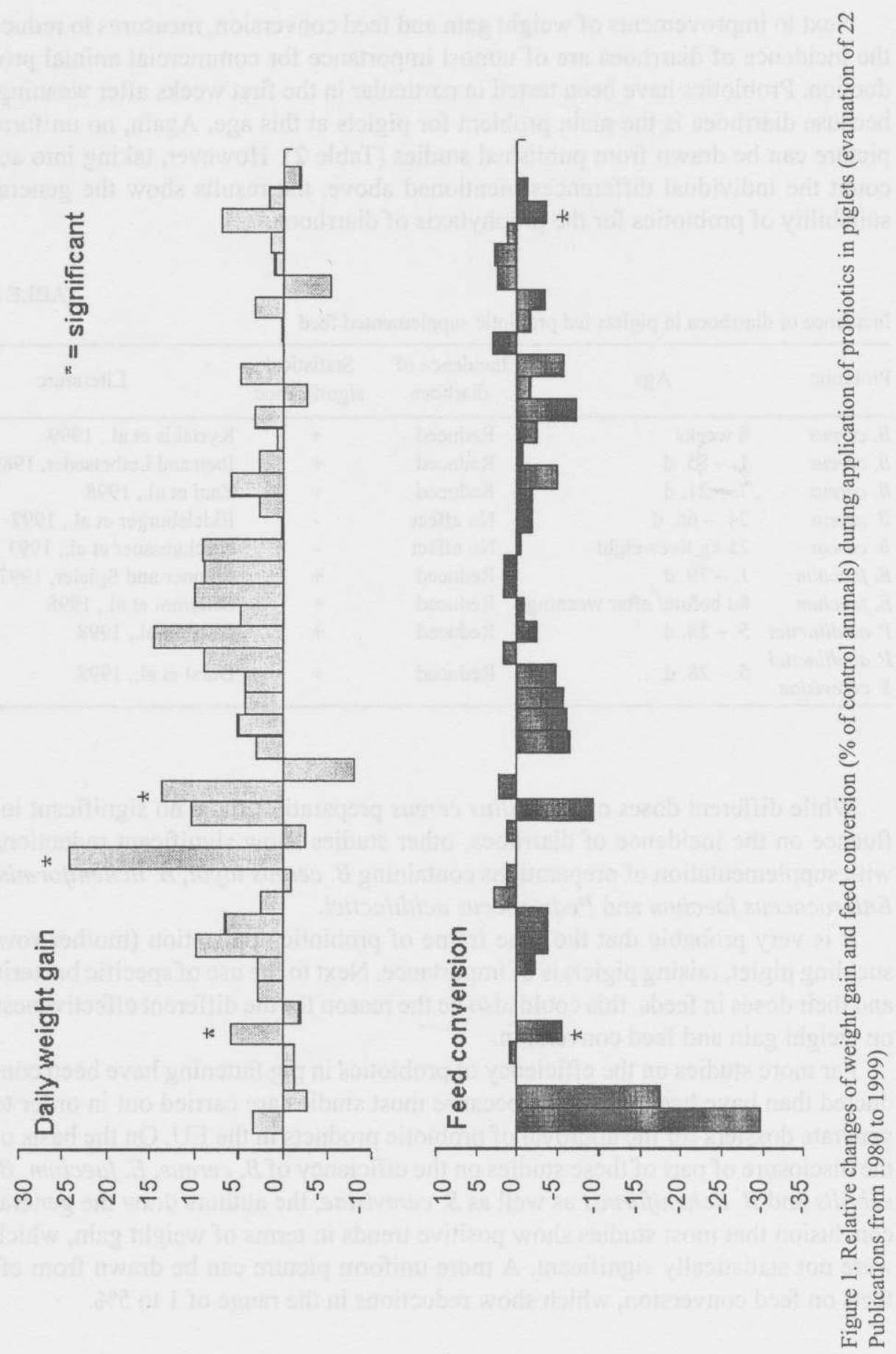
Next to improvements of weight gain and feed conversion, measures to reduce the incidence of diarrhoea are of utmost importance for commercial animal production. Probiotics have been tested in particular in the first weeks after weaning, because diarrhoea is the main problem for piglets at this age. Again, no uniform picture can be drawn from published studies (Table 2). However, taking into account the individual differences mentioned above, the results show the general suitability of probiotics for the prophylaxis of diarrhoea.

TABLE 2

Incidence of diarrhoea in piglets fed probiotic supplemented feed

\begin{tabular}{|c|c|c|c|c|}
\hline Probiotic & Age & $\begin{array}{c}\text { Incidence of } \\
\text { diarhoea }\end{array}$ & $\begin{array}{l}\text { Statistical } \\
\text { significance }\end{array}$ & Literature \\
\hline$\overline{B . \text { cereus }}$ & 8 weeks & Reduced & + & Kyriakis et al., 1999 \\
\hline B. cereus & 1. $-85 . \mathrm{d}$ & Reduced & + & Iben and Leibetseder, 1989 \\
\hline B. cereus & 7. $-21 . \mathrm{d}$ & Reduced & + & Zani et al., 1998 \\
\hline B. cereus & 24. $-66 . d$ & No effect & - & Eidelsburger et al., 1992 \\
\hline B. cereus & $25 \mathrm{~kg}$ liveweight & No effect & - & Kirchgessner et al, 1993 \\
\hline E. faecium & $1 .-70 . \mathrm{d}$ & Reduced & + & Männer and Spieler, 1997 \\
\hline E. faecium & $8 \mathrm{~d}$ before/ after weaning & Reduced & + & Schumm et al., 1998 \\
\hline P. acidilactici & 5. $-28 . \mathrm{d}$ & Reduced & + & Durst et al., 1998 \\
\hline $\begin{array}{l}P \text {. acidilactici } \\
\text { S. cerevisiae }\end{array}$ & 5. $-28 . \mathrm{d}$ & Reduced & + & Durst et al., 1998 \\
\hline
\end{tabular}

While different doses of a Bacillus cereus preparation show no significant influence on the incidence of diarrhoea, other studies show significant reductions with supplementation of preparations containing $B$. cereus toyoi, B. licheniformis, Enterococcus faecium and Pediococcus acidilactici.

It is very probable that the time frame of probiotic application (mother sow, suckling piglet, raising piglet) is of importance. Next to the use of specific bacteria and their doses in feeds, this could also be the reason for the different effectiveness on weight gain and feed conversion.

Far more studics on the efficiency of probiotics in pig fattening have been conducted than have been published because most studies are carried out in order to generate dossiers for the approval of probiotic products in the EU. On the basis of the disclosure of part of these studies on the efficiency of $B$. cereus, E. faecium, $B$. subtilis and $B$. licheniformis as well as $S$. cerevisiae, the authors draw the general conclusion that most studies show positive trends in terms of weight gain, which were not statistically significant. A more uniform picture can be drawn from effects on feed conversion, which show reductions in the range of 1 to $5 \%$. 


\section{Poultry}

Probiotics have also been applied as feed additives in broiler and turkey fattening. Evaluation of the literature shows that more significant results were obtained for broiler fattening than for piglets (Figure 2). This is probably due to the higher numbers of animals used, which may even out individual differences among animals.

The exclusion of pathogenic bacteria is especially important in newly hatched broiler chickens as they do not receive maternal antibodies like young mammals.
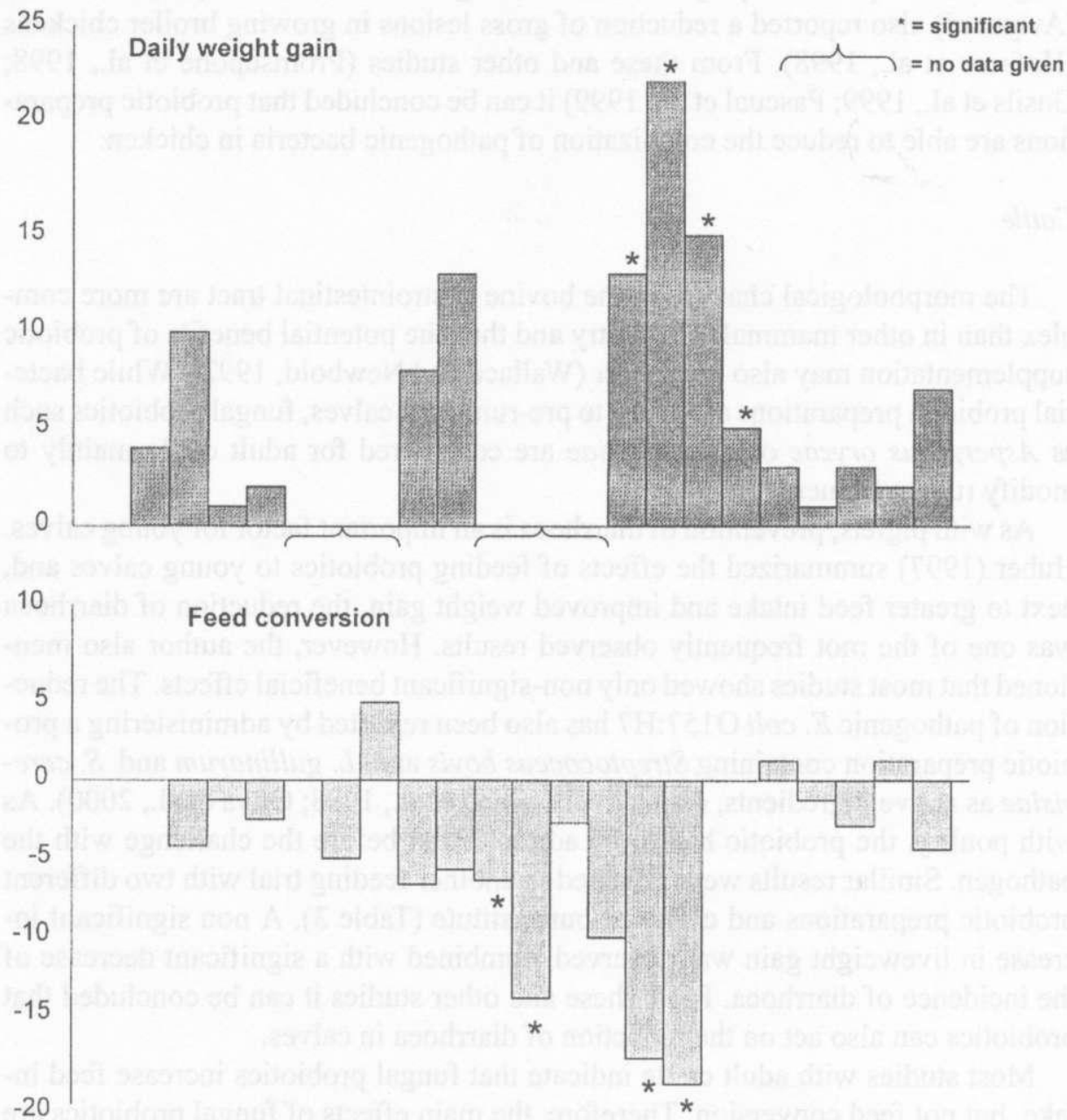

Figure 2. Relative changes of weight gain and feed conversion ( $\%$ of control animals) during application of probiotics in broiler (evaluation of 7 Publications from 1973 to 2000) 
Furthermore, in modern production methods the newly hatched chick has no contact with maternal faeces and thus no maternal spectrum of antigens is presented, allowing the development of an active immune system. In order to circumvent these deficiencies, the concept of competitive exclusion has been developed (Mead, 2000 ) and can also be applied to probiotics.

A challenge trial with the pathogen Salmonella pullorum has shown that the application of an E. faecium strain inhibited mortality when it was administered to newly hatched chickens, but only when the probiotic was administered before the challenge (Audisio et al., 2000). Another challenge study with Clostridium perfringens and a probiotic preparation consisting of more than one probiotic strain (Aviguard) also reported a reduction of gross lesions in growing broiler chickens (Hofacre et al., 1998). From these and other studies (Promsopone et al., 1998; Gusils et al., 1999; Pascual et al., 1999) it can be concluded that probiotic preparations are able to reduce the colonization of pathogenic bacteria in chicken.

\section{Cattle}

The morphological changes in the bovine gastrointestinal tract are more complex than in other mammals or poultry and thus the potential benefits of probiotic supplementation may also be greater (Wallace and Newbold, 1992). While bacterial probiotic preparations are given to pre-ruminant calves, fungal probiotics such as Aspergillus oryzae or $S$. cerevisiae are considered for adult cattle mainly to modify rumen fermentation.

As with piglets, prevention of diarrhoea is an important factor for young calves. Huber (1997) summarized the effects of feeding probiotics to young calves and, next to greater feed intake and improved weight gain, the reduction of diarrhoea was one of the mot frequently observed results. However, the author also mentioned that most studies showed only non-significant beneficial effects. The reduction of pathogenic $E$. coli $\mathrm{O} 157: \mathrm{H} 7$ has also been reported by administering a probiotic preparation containing Streptococcus bovis and L. gallinarum and S. cerevisiae as active ingredients, respectively (Zhao et al., 1998; Ohya et al., 2000). As with poultry, the probiotic had to be administered before the challenge with the pathogen. Similar results were obtained in another feeding trial with two different probiotic preparations and calves at our institute (Table 3). A non significant increase in liveweight gain was observed, combined with a significant decrease of the incidence of diarrhoea. From these and other studies it can be concluded that probiotics can also act on the reduction of diarrhoea in calves.

Most studics with adult cattle indicate that fungal probiotics increase feed intake, but not feed conversion. Therefore, the main effects of fungal probiotics are regarded as intake-driven and Wallace and Newbold (1992) conclude that the improved rate of breakdown of feedstuffs is the most likely beneficial effect in adult 
TABLE 3

Feeding trial with calves $(50-85 \mathrm{~kg}, \mathrm{n}=20)$ and two different probiotic preparations (Institute for Animal Nutrition, Free University of Berlin)

\begin{tabular}{lccc}
\hline Trial group & $\begin{array}{c}\text { Milk replacer } \\
\text { without probiotic }\end{array}$ & $\begin{array}{c}\text { Milk replacer } \\
\text { with probiotic A }\end{array}$ & $\begin{array}{c}\text { Milk replacer } \\
\text { with probiotic B }\end{array}$ \\
\hline $\begin{array}{l}\text { Weight gain } \\
\text { g/day } \\
\text { relative, \% }\end{array}$ & $\begin{array}{c}797 \pm 97 \\
100\end{array}$ & $859 \pm 139$ & $821 \pm 102$ \\
$\begin{array}{l}\text { Feed conversion } \\
\text { kg DM } / \text { kg weight gain } \\
\text { relative, \% }\end{array}$ & $1.93 \pm 0.12$ & 108 & 103 \\
$\begin{array}{l}\text { Incidence of diarrhoea } \\
n\end{array}$ & 100 & $1.82 \pm 0.10$ & $1.91 \pm 0.08$ \\
relative, \% & & 94 & 99 \\
\hline
\end{tabular}

cattle. However, as fungal probiotics do not survive for long in the rumen, the underlying mechanism for the observed results is still unclear.

\section{ON THE MODES OF ACTION OF PROBIOTICS}

The modes of action of probiotics are not well characterized in general, but there is a lack of knowledge particularly about probiotics that are used as feed additives, mainly because research in this field is directed towards bacteria for human nutrition. As the above-mentioned definition by Fuller postulates, probiotic bacteria should act primarily on intestinal microorganisms in improving their balance. This may apply to "desirable" intestinal bacteria such as lactobacilli and bifidobacteria as well as pathogenic bacteria. However, because of the observed reduction in feed conversion ratio, other probiotic mechanisms that modify the conversion of nutrients also need to be discussed. Factors influencing feed conversion may be found in modified intestinal morphology and histology, kinetics of nutrient transport through the intestinal ephitelium, as well as modified nutrient turnover by intestinal bacteria. There are also indications of beneficial effects on the intestinal immune system and an improved intestinal defense against viral infections.

Due to the very dissimilar origin of probiotic microorganisms (see Table 1) one can also assume dissimilar modes of action. Thus, for microorganisms that are not true inhabitants of the intestine (Bacillus spp., Saccharomyces spp.) different modes of action can be proposed than for intestinal bacteria. For instance, specific effects 
could include the release of dipicolinic acid by spore-forming Bacillus spp. upon germination, receptors for $E$. coli fimbriae on yeast cell walls, or the release of large amounts of lactic acid by intestinal bacteria (Enterococcus spp., Pediococcus spp.). Thus, the following possible modes of action may not be relevant for all probiotic bacteria to the same extent.

\section{INFLUENCE ON INTESTINAL MICROBIAL COMMUNITIES}

The intestine is colonized by a multitude of different bacterial species, of which only a fraction can be cultivated in vitro. Since almost all data on the influence of probiotic bacteria on intestinal microbial communities rely on the cultivation method, only a partial picture about probiotic modifications can be drawn from these results. Nevertheless, it could be shown by cultivation of intestinal contents on selective media that the application of $10^{8}$ colony forming units (CFU) of a $B$. cereus preparation per $\mathrm{kg}$ feed to piglets reduced CFU for lactobacilli/bifidobacteria, eubacteria and $E$. coli in the duodenum and jejunum, but increased respective CFU in the ileum, caecum and colon (Gedek et al., 1993). A significant reduction of $E$. coli $\mathrm{CFU}$ in the small intestine of piglets was also noted when an E. faecium preparation was applied (Männer and Spieler, 1997). At the same time, lactobacilli and enterococci CFU increased as a trend and in a statistically significant manner, respectively. However, it has to be taken into account that influences on intestinal microbial communities are dose dependent as well as dependent on location and time of sampling (Gedek et al., 1993; Thelen and Pallauf, 1996). The use of another method (bacterial growth capacities of mucosal samples incubated in liquid selective media) also shows that $B$. cereus reduces the development of mucosa-associated enterobacteria in suckling piglets (Figure 3). However, the effect diminished as piglets aged and growth capacities changed after weaning (Jadamus et al., 2000).

Although these findings confirm probiotic influences on selected intestinal bacterial populations, its consequences for the host animal are largely unknown. Therefore, other studies on modifications of intestinal microbial communities are needed, such as occurrence and abundance of bacterial virulence factors, adhesion and colonization of pathogenic bacteria as well as bacterial metabolism. These studies require the development and application of molecular biology methods.

The results of studies on the ability of probiotic bacteria to reduce the colonization of pathogenic bacteria are ambiguous. Challenge studies with piglets and E. coli $\mathrm{O} 141: \mathrm{K} 85$ showed no influence on clinical symptoms, mortality or excretion of haemolytic $E$. coli (De Cupere et al., 1992). In a study conducted in our institute, it could also be shown that although the colonization with mucosa-associated enterobacteria was reduced by a probiotic $B$. cereus preparation (Jadamus et 

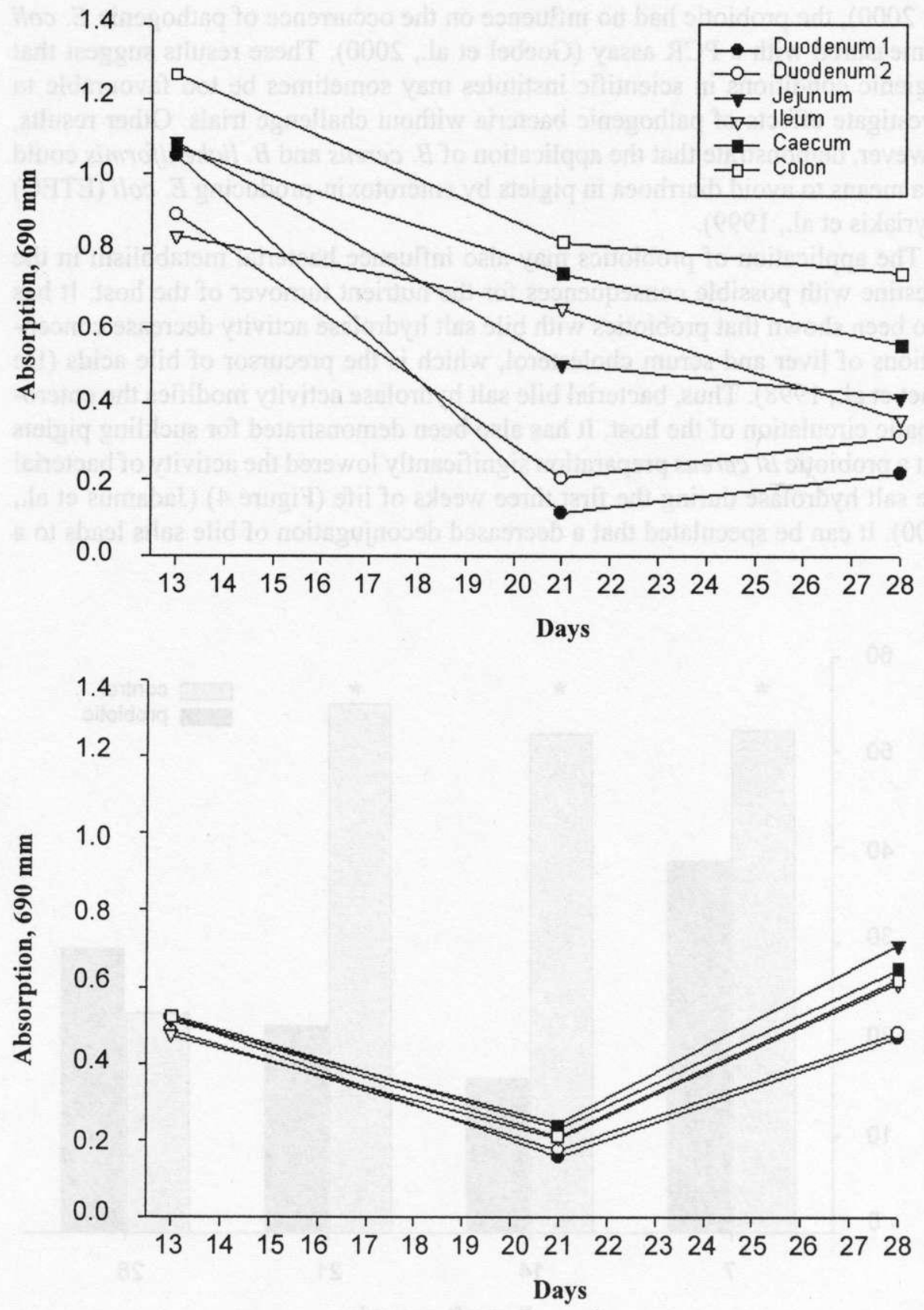

Figure 3. Influence of a Bacillus probiotic on the development of enterobacterial growth capacities in mucosa samples from piglets 
al., 2000), the probiotic had no influence on the occurrence of pathogenic $E$. coli as measured with a PCR assay (Goebel et al., 2000). These results suggest that hygienic conditions in scientific institutes may sometimes be too favourable to investigate effects of pathogenic bacteria without challenge trials. Other results, however, demonstrate that the application of $B$. cereus and $B$. licheniformis could be a means to avoid diarrhoea in piglets by enterotoxin-producing $E$. coli (ETEC) (Kyriakis et al., 1999).

The application of probiotics may also influence bacterial metabolism in the intestine with possible consequences for the nutrient turnover of the host. It has also been shown that probiotics with bile salt hydrolase activity decrease concentrations of liver and serum cholesterol, which is the precursor of bile acids (De Smet et al., 1998). Thus, bacterial bile salt hydrolase activity modifies the enterohepatic circulation of the host. It has also been demonstrated for suckling piglets that a probiotic $B$. cereus preparation significantly lowered the activity of bacterial bile salt hydrolase during the first three weeks of life (Figure 4) (Jadamus et al., 2000). It can be speculated that a decreased deconjugation of bile salts leads to a

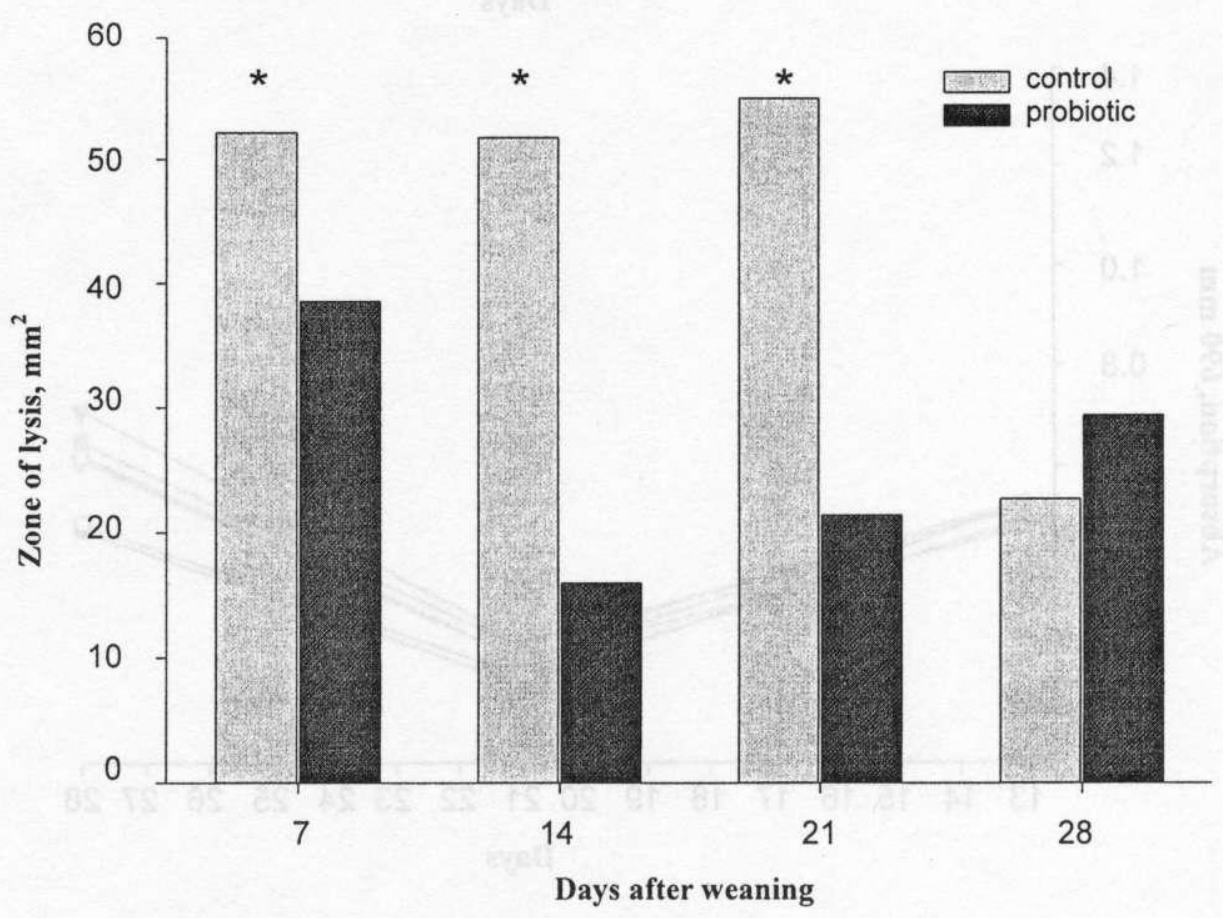

Figure 4. Activity of bacterial bile salt deconjugating enzymes in piglet jejunum during the application of probiotics in piglets $(*=$ statistically significant, $\mathrm{P}<0.05)$ 
decreased ability to digest fats, because fat micelle formation is limited. This would be especially important for young animals. However, probiotics with bile salt hydrolase activity may not be desired in animal nutrition, as they may negatively affect fat micelle formation.

For the future it can be said with confidence that studies on direct or indirect interactions between probiotic and pathogenic bacteria will lead to considerable increase in knowledge.

The possible modes of probiotic action on intestinal bacteria can be summarized as follows:

- aggregation of probiotics and pathogenic bacteria

- competitive adhesion of probiotics to epithelial receptors

- production of specific substances (bacteriocins, reuterin, dipicolinic acid)

- competition for nutrients between probiotic and undesired bacteria

- $\mathrm{pH}$-reduction by production of acid

- reduction of bacterial bile salt deconjugation

- increase of desired intestinal bacteria.

In order to understand the causal relationships that lead to the observed improvements in weight gain and feed conversion or general health of animals, the possible interactions between bacteria in the intestine and the host animal must be studied. Of special significance are interactions between the metabolism of the host and the metabolic activity of intestinal bacterial populations. For instance, some intestinal bacteria produce toxic metabolites that must be disposed of by the host. Other intestinal bacteria are able to deconjugate bile acids, which are essential for fat digestion and may thus directly influence the host's conversion of nutrients and energy.

\section{INFLUENCE ON THE INTESTINAL MUCOSA AND FUNCTION OF THE EPHITELIUM}

Modification of intestinal mucosa morphology could be demonstrated by providing a $B$. cereus preparation to piglets (Klein and Schmidts, 1997). Four weeks of probiotic application led to a statistically significant enlargement of the mucosa surface and villus height in the jejunum. This type of modification may well influence nutrient resorption.

The microstructure of the ephitelium is of great functional importance, for nutrient transport (absorption and secretion) as well as maintenance of transcellular and paracellular barrier functions. This structure inhibits uncontrolled passage of substances and provides a barrier against infection with intestinal bacteria. Moreover, carbohydrate structures on the mucosal surface are used for adhesion by pathogenic and nonpathogenic bacteria (Mack et al., 1999). 
Proliferation of mucosal cells as well as their programmed cell death (apoptosis) are influenced to a considerable degree by adhering bacteria. Thus, it is probable that one mode of probiotic action can be found in this mechanism. This subject also demands considerably more data than is available today.

The first studies on transport- and electrophysiological parameters of the porcine intestinal mucosa indicate increased paracellular impermeability of tissues from animals that were fed a B. cereus- or Saccharomyces boulardii-supplemented feed (Breves et al., 2000). In addition, in uptake studies on isolated membrane vesicles, an increase in the maximal transport rate for glucose was measured. This also indicates that probiotics are able to modify the function of the intestinal mucosa.

\section{INFLUENCE ON THE IMMUNE SYSTEM}

Studies on the effects of probiotics on the immune system are almost exclusively carried out with mice as the model animal. The results show that probiotics such as L. acidophilus or Bifidobacterium bifidum are able to target specific immune functions. However, although numerous in vivo and in vitro studies were conducted, the underlying mechanisms are still unknown (Erickson and Hubbart, 2000; Rolfe, 2000).

For instance, the application of lactic acid bacteria enhances the release of secretory IgA (Vitini et al., 2001). Moreover, different Lactobacillus-species have a specific effect on the production of cytokins by intestinal leukocytes (Maassen et al., 2000). The stimulation of phagocytic activity of peripheral blood leukocytes and peritoneal macrophages has also been reported for a yeast preparation (Rodriguez et al., 2000). Since extensive development processes occur in the intestine, especially in the first weeks of life, the development of the local immune system of very young animals is determined by intestinal microbial populations. Studies with farm animals also detected increased production of antibodies against specific antigens (Panda et al., 2000).

However, it has to be kept in mind that challenge studies show a rather fast positive response, thus making it unlikely that the immune system is involved in the resistance against specific pathogenic bacteria (Fuller, 1999). There is a dire need for systematic studies on this field of research in order to specifically target probiotics to support the immune system and stabilize health.

\section{CONCLUSIONS}

In animal nutrition, probiotics are viable microorganisms, which lead to beneficial effects on weight gain and feed conversion as well as to a reduction of the 
incidence of diarrhoea. Statistically significant results in probiotic studies are rare, mainly because of individual reactions of the animals. In addition, very different experimental setups can be considered responsible for the ambiguous picture the literature on probiotics presents today.

The modes of action, which lead to beneficial effects are only partly known. It is very probable that the impact of probiotics on pathogenic and nonpathogenic intestinal bacteria is of prime importance. However, modifications of microstructures and barrier functions of intestinal tissues as well as reactions of the immune system seem to be involved in the overall effect, directly or as a consequence of modified bacterial populations. In order to specifically improve probiotics and their application for further specific indications, more research is needed to determine their underlying mechanisms.

\section{REFERENCES}

Audisio C.M., Oliver G., Apella M.C., 2000. Protective effect of Enterococcus faecium J96, a potential probiotic strain, on chicks infected with Salmonella Pullorum. J. Food Protect. 10, 13331337

Breves G., Walter C., Burmester M., Schröder B., 2000. In vitro studies on the effects of Saccharomyces boulardii and Bacillus cerets var. toyoi on nutrient transport in pig jejunum. J. Anim. Physiol. Anim. Nutr. 84, 9-20

De Cupere F., Deprez P., Demeulenaere D., Muylle E., 1992. Evaluation of the effect of 3 probiotics on experimental Escherichia coli enterotoxaemia in weaned piglets. J. Vet. Med. B. 39, 277-284

DiRienzo D.B., 2000. Symposium: Probiotic bacteria: Implications for human health. J. Nutr. 130, $382 \mathrm{~S}-383 \mathrm{~S}$

De Smet I., De Boever P., Verstraete W., 1998. Cholesterol lowering in pigs through enhanced bacterial bile salt hydrolase activity. Brit. J. Nutr. 79, 185-194

Durst L., Feldner M., Gedek B., Eckel B., 1998. Bakterien als Probiotikum in der Sauenfütterung und der Ferkelaufzucht. Kraftutter 9, 356-364

Eidelsburger U., Kirchgessner M., Roth, F.X., 1992. Zum Einfluss von Fumarsäure, Salzsäure, Natriumformiat, Tylosin und Toyocerin aur tägliche Zunahmen, Futteraufnahme, Futterverwertung und Verdaulichkeit: 11. Mitteilung. Untersuchungen zur nutritiven Wirksamkeit von organischen Säuren in der Ferkelaufzucht. J. Anim. Physiol. Anim. Nutr. 68, 82-92

Erickson K.L., Hubbard N.E., 2000. Probiotic immunomodulation in health and disease. Symposium: Probiotic bacteria: Implications for human health. J. Nutr. 130, 403S-409S

Freitag M., Hensche H.-U., Schulte-Sienbeck H., Reichelt B., 1998. Kritische Betrachtung des Einsatzes von Leistungsförderern in der Tierernährung. Forschungsberichte der Universität Paderborn, No. 8

Fuller R., 1989. Probiotics in man and animals. J. Appl. Bacteriol. 66, 365-378

Fuller R., 1999. Probiotics for Farm Animals. In: Probiotics: A Critical Review. Horizon Scientific Press, Wymondham (UK), pp. 15-28

Gedek B., Kirchgessner M., Wiehler S., Bott A., Eidelsburger U., Roth F.X., 1993. Zur nutritiven Wirksamkeit von Bacillus cereus als Probiotikum in der Ferkelaufzucht. 2. Mitteilung. Einfluss 
auf Keimzahlen, Zusammensetzung und Resistenzeigenschaften der gastrointestinalen und faecalen Mikroflora. Arch. Anim. Nutr. 44, 215-226

Goebel S., Vahjen W., Jadamus A., Simon O., 2000. PCR assay for detection of porcine pathogenic Escherichia coli virulence factors in the gastrointestinal tract of piglets fed a spore forming probiotic. Proc. Soc. Nutr. Physiol. 9, 64

Gusils C., Gonzalez S.N., Oliver G., 1999. Some probiotic properties of chicken lactobacilli, Can. J. Microbiol. 45, 981-987

Hofacre C.L., Froyman R., Gautrias B., George B., Goodwin M.A., Brown J., 1998. Use of Aviguard and other intestinal bioproducts in experimental Clostridium perfringens-associated necrotizing enteritis in broiler chickens. Avian Dis, 42, 579-584

Huber J.T., 1997. Probiotics in cattle. In: R. Fuller (Editor). Probiotics 2 - Applications and Practical Aspects. Chapman and Hall, London, pp. 162-180

Iben Ch., Leibetseder J., 1989. Untersuchung der leistungsfördernden Wirkung von Toyocerin in der Ferkelaufzucht. Wien. Tierärztl. Monatschr. 76, 363-366

Jadamus A., Vahjen W., Simon O., 2000. Influence of the probiotic bacterial strain, Bacillus cereus var. toyoi, on the development of selected microbial groups adhering to intestinal mucosal tissues of piglets. J. Anim. Fced Sci. 9, 347-362

Kirchgessner M., Roth R.X., Eidelsburger U., Gedek B., 1993. Zur nutritiven Wirksamkeit von Bacillus cereus als Probiotikum in der Ferkelaufzucht. 1. Mittcilung. Einfluss auf Wachstumsparameter und gastrointestinales Milieu. Arch. Anim. Nutr. 44, 111-121

Klein U., Schmidts H.L., 1997. Zum Einfluss des Bioregulators Paciflor" auf die Morphologie der Dünndarmmukosa beim Schwcin. Proc. Soc. Nutr. Physiol. 6, 41

Kyriakis S.C., Tsiloyiannis V.K., Vlemmas J., Sarris K., Tsinas A.C., Alexopoulos C., Jansegers L., 1999. The effect of probiotic LSP 122 on the control of post-weaning diarrhoea syndrome of piglets. Res. Vet. Sci. 67, 223-228

Mack D.R., Michael S., Wie S., McDougall L., Holligsworth M.A., 1999. Probiotics inhibit enteropathogenic Escherichia coli adherence in vitro by inducing intestinal mucin gene expression. Amer. J. Physiol. 276, G941-G950

Männer K., Spicler A., 1997. Probiotics in piglets - an alternative to traditional growth promoters. Microecol. Therapy 26, 243-256

Maassen C.B., van Holten-Neelen C., Balk F., den Bak-Glashouwer M.J., Leer R.J., Laman J.D., Boersma W.J., Claassen E., 2000. Strain-dependent induction of cytokine profiles in the gut by orally administered Lactobacillus strains. Vaccine 18, 2613-2623

Mead G.C., 2000. Prospects for 'competitive exclusion' treatment to control salmonellas and other foodborne pathogens in poultry. Vet. J. 159, 111-123

Metchnikoff E., 1907. The Prolongation of Life. Heinemann, London

Ohya T., Marubashi T., Ito H., 2000. Significance of fecal volatile fatty acids in shedding of Escherichia coli $\mathrm{O} 157$ from calves: experimental infection and preliminary use of a probiotic product. J. Vet. Med. Sci. 62, 1151-1155

Pascual M., Hugas M., Badiola J.I., Monfort J.M., Garriga M., 1999. Lactobacillus salivarius CTC2197 prevents Salmonella enteritidis colonization in chickens. Appl. Environ. Microbiol. 65, 49814986

Promsopone B., Morishita T.Y., Aye P.P., Cobb C.W., Veldkamp A., Clifford J.R., 1998. Evaluation of an avian-specific probiotic and Salmonella typhimurium - Specific antibodies on the colonization of Salmonella typhimurium in broilers. J. Food. Protect. 61, 76-80

Rodrigues A.C., Cara D.C., Fretez S.H., Cunha F.Q., Vieira E.C., Nicoli J.R., Vieira L.Q., 2000. Saccharomyces boulardii stimulates slgA production and the phagocytic system of gnotobiotic mice. J. Appl. Microbiol. 89, 404-414 
Rolfe R.D., 2000. The role of probiotic cultures in the control of gastrointestinal health. Symposium: Probiotic bacteria: Implications for human health. J. Nutr. 130, 396S-402S

Sanders M.E., 2000. Consideration for use of probiotic bacteria to modulate human health. Symposium: Probiotic bacteria: Implications for human bealth. J. Nutr. 130, 384S-390S

Schumm H., Pohl R., Willeke H., 1990. Ergebnisse des Einsatzes von Suiferm bei Absatzferkeln mit Durchfällen zur Aufrechterhaltung und Wiederherstellung der gesunden Darmflora. Tierärztl. Umsch. 45, 402-411

Thelen U., Pallauf J., 1996. Effect of Bacillus cereus on the composition of the intestinal flora of the early weaned piglet. Proc. Soc. Nutr. Physiol. 5, p. 144

Tuschy D., 1986. Verwendung von "Probiotika" als Leistungsförderer in der Tierernährung. Übers. Tierernähr. 14, 157-178

Vitini E., Alvarez S., Medina M., Medici M., de Budeguer M.V., Perdigon G., 2000. Gut mucosal immunostimulation by lactic acid bacteria. Biocell 24, 223-232

Wallace R.J., Newbold C.J., 1992. Probiotics for ruminants. In: R. Fuller (Editor). Probiotics - The Scientific Basis. Chapman and Hall, London, pp. 317-353

Zani J.L., Weykamp da Cruz F., Freitas dos Santos A., Gil-Turnes C., 1998. Effect of probiotic CenBiot on the control of diarrhoea and feed efficiency in pigs. J. Appl. Microbiol. 84, 68-71

Zhao T., Doyle M.P., Harmon B.G., Brown C.A., Mueller P.O., Parks A.H., 1998. Reduction of carriage of enterohemorrhagic Escherichia coli $\mathrm{O} 157: \mathrm{H} 7$ in cattle by inoculation with probiotic bacteria. J. Clin. Microbiol. 36, 641-647

\section{STRESZCZENIE}

\section{Probiotyczne dodatki paszowe - skuteczność i oczekiwany sposób dzialania}

Probiotyki są to żywe mikroorganizmy, które - stosowane jako dodatek do pasz dla zwierząt wywierają korzystny wpływ na organizm. $\mathrm{U}$ większości gatunki zwierząt pod wpływem probiotyków zaznacza się tendencja do poprawy uźytkowości, lecz zwiększenie przyrostów i wykorzystanie paszy rzadko można udowodnić statystycznie, głównie z powodu zmienności indywidualnej reakcji zwierząt na probiotyki. W większości doświadczeń stwierdzono jednak istotne zmniejszenie liczby zachorowań na biegunkę u prosiąt i cieląt. W odróżnieniu od żywienia ludzi, gdzie jako preparaty probiotyczne stosuje się powszechnie gatunki Lactobacillus, w żywicniu zwierząt najczęściej stosowanymi mikroorganizmami probiotycznymi są Enterococcus spp., drożdże Saccharomyces oraz Bacillus spp., tworzące zarodniki. Ponadto u ludzi dąży się do uzyskania długotrwalego wpływu probiotyków na stan zdrowia i długowicczność, natomiast celem stosowania probiotyków w nowoczesnej produkcji zwierzęcej jest szybka poprawa przyrostów i wykorzystania paszy. Oznacza to, że wyniki badań nad probiotykami w żywieniu ludzi nie mogą być przenoszone bezpośrednio do żywienia zwierząt.

Chociaż do stosowania w Unii Europejskiej zostało czasowo dopuszczonych 19 preparatów probiotycznych, mechanizm ich korzystnego działania nie jest w pełni poznany. Jest bardzo prawdopodobne, że największe znaczenie ma działanie probiotyków na patogenne i niepatogenne bakterie jelitowe. Wydaje się jednak, że ogólny efckt zależny od modyfikacji mikostruktur i bariery jelitowej oraz reakcji systemu odpornościowego, w sposób bezpośredni, lub w wyniku zmiany populacji bakteryjnej. Potrzebne są dalsze badania nad mechanizmami działania probiotyków w celu poprawy preparatów i zwiększenia skuteczności ich działania w określonych warunkach. 